\title{
Specific Immunoassays for Placental Alkaline Phosphatase As a Tumor Marker
}

\author{
Sérvio T. Stinghen, ${ }^{1}$ Juliana F. Moura, ${ }^{1}$ Patrícia Zancanella, ${ }^{1}$ Giovanna A. Rodrigues, ${ }^{1}$ \\ Mara A. Pianovski, ${ }^{2}$ Enzo Lalli, ${ }^{3}$ Dodie L. Arnold, ${ }^{4}$ João C. Minozzo,, ${ }^{5}$ uis G. Callefe, ${ }^{1}$ \\ Raul C. Ribeiro, ${ }^{6}$ and Bonald C. Figueiredo ${ }^{1,7}$ \\ ${ }^{1}$ Centro de Genética Molecular e Pesquisa do Câncer em Crianças (CEGEMPAC), Rua Agostinho Leão Júnior, \\ 400 Alto da Glória, Curitiba, PR, CEP 80030-110, Brazil \\ ${ }^{2}$ Division of Pediatric Hematology and Oncology, Department of Pediatrics, Federal University of Paraná, Curitiba, PR, \\ CEP 80060-000, Brazil \\ ${ }^{3}$ Institut de Pharmacologie Moléculaire et Cellulaire, CNRS UMR 6097, 06560 Valbonne Sophia Antipolis, France \\ ${ }^{4}$ Meharry Medical College, Nashville, TN 37208, USA \\ ${ }^{5}$ Center for Research and Production of Immunoglobulins (CPPI), Rua Targino da Silva s/n, Piraquara, PR, \\ CEP 83302-160, Brazil \\ ${ }^{6}$ St. Jude Children's Research Hospital, Department of Hematology and Oncology and International Outreach Program, \\ 332 North Lauderdale, Memphis, TN 38105, USA \\ ${ }^{7}$ Research Institute Pelé Pequeno Príncipe (IPPP), Avenida Silva Jardim, 1632 Água Verda, Curitiba, PR, \\ CEP 80250-200, Brazil
}

Received 23 December 2005; Revised 1 June 2006; Accepted 6 June 2006

\begin{abstract}
Human placental (hPLAP) and germ cell (PLAP-like) alkaline phosphatases are polymorphic and heat-stable enzymes. This study was designed to develop specific immunoassays for quantifying hPLAP and PLAP-like enzyme activity (EA) in sera of cancer patients, pregnant women, or smokers. Polyclonal sheep anti-hPLAP antibodies were purified by affinity chromatography with whole hPLAP protein (ICA-PLAP assay) or a synthetic peptide (aa 57-71) of hPLAP (ICA-PEP assay); the working range was 0.1$11 \mathrm{U} / \mathrm{L}$ and cutoff value was $0.2 \mathrm{U} / \mathrm{L}$ EA for nonsmokers. The intra- and interassay coefficients of variation were $3.7 \%-6.5 \%$ (ICAPLAP assay) and 9.0\%-9.9\% (ICA-PEP assay). An insignificant cross-reactivity was noted for high levels of unheated intestinal alkaline phosphatase in ICA-PEP assay. A positive correlation between the regression of tumor size and EA was noted in a child with embryonal carcinoma. It can be concluded that ICA-PEP assay is more specific than ICA-PLAP, which is still useful to detect other PLAP/PLAP-like phenotypes.
\end{abstract}

Copyright (c) 2006 Sérvio T. Stinghen et al. This is an open access article distributed under the Creative Commons Attribution License, which permits unrestricted use, distribution, and reproduction in any medium, provided the original work is properly cited.

\section{INTRODUCTION}

Human alkaline phosphatases (ALP) are dimeric enzymes anchored by glycosylphosphatidylinositol to the cell membrane. Specific phospholipases can cleave ALP from the cell membrane, producing free ALP in the serum [1-3]. ALP consists of a family of four isozymes: (1) placental ALP (PLAP; or hPLAP in the case of human placental ALP), and (2) germ cell ALP (PLAP-like or GCAP), which are both stable at $65^{\circ} \mathrm{C}$ and present $98 \%$ homology; as well as (3) intestinal ALP (IAP), and (4) nonspecific tissue ALP (TNAP) or liver/bone/kidney ALP, which are not stable at $65^{\circ} \mathrm{C}$ and present $88 \%$ and $56 \%$ homology with PLAP, respectively [4$6]$.
PLAP is encoded by a highly polymorphic gene of which 3 common alleles and at least 18 rare alleles exist; giving origin to 48 known phenotypes [7-9]. The PLAP-like enzyme is encoded by 4 alleles with at least 10 known phenotypes [9-12]. PLAP and PLAP-like enzymes may form heterodimers [13].

PLAP is synthesized in the placental syncytiotrophoblast starting after the 12th week of pregnancy [14] and is probably involved in transplacental IgG transport $[15,16]$. The PLAP-like enzyme is primarily synthesized in testis, cervix, and thymus. Trace amounts are synthesized in placenta and lung tissues $[17,18]$. In healthy, nonsmoking adults PLAP and PLAP-like enzyme activities represent less than $1 \%$ of all ALP $[19,20]$. Smoking causes elevated serum concentrations 
of the PLAP-like enzyme, which may diminish the value of PLAP-like enzyme as a tumor marker. Serum concentrations of PLAP-like enzyme return to the normal range after 1-2 months of smoking cessation [21-23].

Ectopic expression of PLAP is associated with cancer of ovary, testis, lung, and colorectal tract [14]. Ectopic expression of the PLAP-like enzyme is associated with testicular cancers: intratubular germ cell neoplasia, unclassified (IGCNU), seminoma, embryonal carcinoma, and choriocarcinoma [23-25]. Roelofs et al [26] using RT-PCR have shown that seminoma and IGCNU express predominantly the PLAP-like enzyme, while embryonal carcinomas express variable amounts of PLAP and PLAP-like enzymes.

Due to their high homology, PLAP and PLAP-like enzymes cannot be easily distinguished using polyclonal or monoclonal antibodies. However, the specific monoclonal antibodies C2 and 17E3 may recognize only PLAP [27, 28]. In general, the enzyme activity is usually considered to include both PLAP and PLAP-like.

Elevated serum concentrations of PLAP and PLAP-like enzymes were found in $25 \%-65.5 \%$ of patients with ovarian cancer $[19,29-35]$, and $22 \%-89 \%$ of patients with testicular neoplasms [23, 36-42]. Variable values of PLAP and PLAP-like enzyme activity or serum concentrations may depend upon the method and antibody used for detection, as well as upon cancer type or staging. Seminomas can have a similar molecular profile to embryonal carcinoma; explaining aberrant immune profiles [43].

Testing of serum samples from ovarian cancer patients demonstrated that testing for PLAP/PLAP-like enzyme activity is less sensitive than testing for CA $125(71 \%-85 \%)$ and alpha-fetoprotein (AFP) (88\%) [44]; however, testing for PLAP/PLAP-like enzyme activity was considered to be the best survival indicator [35], and more specific (PLAP/PLAPlike; 95\%) than CA 125 (71\%) [31]. Weissbach et al [23] have demonstrated that serum PLAP/PLAP-like was more sensitive $(56 \%)$ than other tumor markers, such as HCG (35\%) and $\mathrm{LDH}(34 \%)$, in the evaluation of seminoma patients.

Polyclonal antibodies against PLAP and PLAP-like enzymes may cross-react with IAP isozyme. In contrast, monoclonal antibodies may not detect all ALP phenotypes if the epitope is absent (eg, because of polymorphism, or if it has been cleaved by phospholipases) $[45,46]$.

To eliminate both of these latter problems, this research was designed to develop and test two sensitive and specific immunoassays for PLAP and PLAP-like enzyme activities using two sheep anti-hPLAP polyclonal antibodies purified by affinity chromatography.

\section{MATERIALS AND METHODS}

\section{Animal immunization}

One adult sheep was immunized with hPLAP (SigmaAldrich, St Louis, Mo, USA) through seven subcutaneous injections at 14-day intervals. The emulsion for the first injection was prepared using $2 \mathrm{mg}$ of hPLAP dissolved in $1 \mathrm{~mL}$ of $0.05 \mathrm{M}$ phosphate buffered saline (PBS; $\mathrm{pH} 7.4$ ) and $1 \mathrm{~mL}$ of Freund's complete adjuvant (Sigma-Aldrich, St Louis, Mo, USA). The remaining 6 injections were prepared using Freund's incomplete adjuvant.

Optimal animal immunization was indicated by high serum concentration of anti-hPLAP. This was measured by two different protocols: double immunodiffusion test and indirect ELISA. Animal sera were obtained $(0.8 \mathrm{~L})$ and immunoglobulins were precipitated in a saturated ammonium sulfate solution.

\section{Purification of anti-hPLAP antibodies}

Specific anti-hPLAP antibodies were purified through an affinity chromatography column. One gram of cyanogen bromide-activated Sepharose (CNBr-Sepharose; Sigma-Aldrich, St Louis, Mo, USA) was coupled to $20 \mathrm{mg}$ of hPLAP according to previously described protocols [47].

Aliquots of sheep immunoglobulins were dissolved in PBS and circulated through the column at a flow rate of $20 \mathrm{~mL} / \mathrm{h}$ overnight at $4^{\circ} \mathrm{C}$. Afterwards, the column was washed with PBS until absorbance $(280 \mathrm{~nm})$ of the eluted solution had returned to baseline. Recovery of the immunoglobulins bound to the hPLAP-Sepharose column was performed by washing the column with $0.1 \mathrm{M}$ glycine-HCL, $0.15 \mathrm{M} \mathrm{NaCl}, \mathrm{pH} 2.8$, until an immunoglobulin peak was obtained. Finally, the column was washed with PBS until the absorbance returned to baseline. The eluted solution containing anti-hPLAP antibodies was dialyzed overnight at $4^{\circ} \mathrm{C}$ in PBS.

\section{Purification of anti-amino acid 57-71 peptide}

A synthetic peptide extending from amino acid (aa) residue 57 to 71 of hPLAP, made by a technique reported by Kates and Albericio [48], was generously synthesized and provided by the Biophysics Laboratory from UNIFESP (São Paulo, SP). Selected peptide aa 57-71 of hPLAP differs in 2 residues from PLAP-like, 3 residues from IAP, and 9 residues from TNAP [6]. This peptide sequence was chosen because it contains free epitope(s) in an unfolded loop and accessible to antibodies.

The synthetic peptide $(22.9 \mathrm{mg})$ was immobilized to $1.0 \mathrm{~g}$ of CNBr-Sepharose according to previously described methods [47]. Aliquots containing purified anti-hPLAP antibodies were circulated through the Sepharose-aa 57-71 peptide column at a flow rate of $20 \mathrm{~mL} / \mathrm{h}$. Unbound anti-hPLAP antibodies (PLAP-Ab) that did not recognize the aa 57-71 peptide were eluted and separated to prepare the first immunoassay, which was named ICA-PLAP. Anti-aa 57-71 peptide antibodies (PEP-Ab) were eluted and collected as described above. These antibodies were separated to prepare the second immunoassay, called ICA-PEP.

\section{Standard curve}

Purified hPLAP (11 U/mg) (Sigma-Aldrich, St Louis, MO, USA), $3 \mathrm{~g} / \mathrm{L}$ in distilled water, was used as a control, diluted in 
$0.25 \%$ casein, $0.05 \%$ Tween 20 , and PBS (dilution buffer) to obtain hPLAP activities ranging from $0.17-11 \mathrm{U} / \mathrm{L}$. Dilution buffer was used as a zero standard solution.

\section{Specificity}

The purified IAP (3 U/mg) (Calzyme, San Luis Obispo, Calif, USA), $1 \mathrm{~g} / \mathrm{L}$ in distilled water, was used to determine crossreactivity. It was diluted in dilution buffer at concentrations of 0.05-55 U/L. IAP samples were tested with and without heat treatment at $65^{\circ} \mathrm{C}$ for 10 minutes.

\section{Serum samples}

\section{Subjects (smokers and nonsmokers)}

This study was approved by the Ethics Committee at the Hospital of Clinics of the Federal University of Paraná, and samples from serum or tissue were obtained after consent from patients or the patients' parents. Control serum specimens were obtained from 100 healthy adults: 93 serum samples from blood donors representing negative controls (1957 years of age; 39 females and 54 males; 44 nonsmokers and 49 smokers), and 7 serum samples from 7 pregnant women representing positive controls (24-35 years of age; at 12-37 weeks of gestation). Social smokers (1-2 cigarettes per week) or subjects who smoke less than 1 cigarette per day were not included in this study.

\section{A child with embryonal carcinoma (case report)}

An 11.2-year-old girl was admitted to the hospital complaining of abdominal pain for the last 2 months. On admission she presented with an enlarged abdominal volume due to a palpable mass in the lower third of the abdomen. Her height was $141 \mathrm{~cm}$ and body weight was $26 \mathrm{~kg}$; $5 \mathrm{~kg}$ less than 2 months before admission. There was no record of cancer among her relatives. A CT scan revealed an $11 \times 12 \times 16 \mathrm{~cm}$ extragonadal mass located between the bladder and the rectum, extending up to the mesogastrium, at the level of L4. Histological evaluation and immunohistochemistry of tumor specimens obtained from the biopsy were positive for CKAE1/AE3 (multifocal) and Ki67 (90\%), and was negative for AFP, LCA, and CD30 markers, suggesting it to be an embryonal carcinoma at Stage III. Serum samples for PLAP/PLAP-like enzyme activity were collected before, during, and after chemotherapy.

\section{Placental analysis (positive control)}

A tissue sample from a term placenta was obtained and used as a positive control. All samples (sera and tissue) were stored at $-80^{\circ} \mathrm{C}$ until assay. Soluble tissue extracts were obtained as previously described [21].

\section{Immunoassays: ICA-PLAP and ICA-PEP}

A 96-well Nunc MaxiSorp microplate (Nalge Nunc International, Roskilde, Denmark) was coated overnight at $4^{\circ} \mathrm{C}$ with $100 \mu \mathrm{L}$ of a $1.6 \mu \mathrm{g} / \mathrm{mL}$ solution of anti-hPLAP antibodies (ICA-PLAP assay), or an $18.4 \mu \mathrm{g} / \mathrm{mL}$ solution of anti-aa 57-71 peptide antibodies (ICA-PEP assay) in $0.05 \mathrm{M}$ carbonate buffer, $\mathrm{pH}$ 9.6. Afterwards, the wells were washed twice with wash buffer $(0.05 \%$ Tween 20 in saline). Each well was filled with $100 \mu \mathrm{L}$ of blocking buffer ( $2 \%$ casein in PBS) and the plate was incubated for 1 hour at $37^{\circ} \mathrm{C}$. After washing twice with wash buffer, $100 \mu \mathrm{L}$ of a standard solution containing hPLAP (0-11 U/L, range of the standard curve) in dilution buffer $(0.25 \%$ casein, $0.05 \%$ Tween $20, \mathrm{PBS})$, and $100 \mu \mathrm{L}$ of experimental serum sample, or of homogenized tissue supernatant, were added to the wells. After incubation for 1 hour at $37^{\circ} \mathrm{C}$, the plate was washed 5 times with wash buffer and $100 \mu \mathrm{L}$ p-nitrophenyl phosphate substrate was added. After incubation for 5 hours (ICA-PLAP assay) or overnight (ICA-PEP assay) at $37^{\circ} \mathrm{C}$, the enzymatic reaction was stopped through the addition of $50 \mu \mathrm{L}$ of $3 \mathrm{M} \mathrm{NaOH}$. The absorbance $(405 / 620 \mathrm{~nm})$ was measured using a microplate reader (Spectra, Tecan, Zurich, Switzerland). All standards and samples were tested in duplicate. The positive control for all assays was a pool of sera taken from 5 pregnant women and 1 placental extract. Positive samples were retested after heat treatment at $65^{\circ} \mathrm{C}$ for 10 minutes in order to inactivate IAP.

\section{RESULTS}

\section{Production, purification, and titration of antibodies}

Serum from hPLAP-immunized sheep was tested by immunodiffusion in the presence of hPLAP $(1 \mathrm{mg} / \mathrm{mL})$, and the results were positive up to $1: 2$ dilutions. After treatment the animal was given one extra injection of hPLAP. Serum titers were reanalyzed by indirect ELISA 2 weeks later, when adequate immunization was revealed by titers of $1: 256000$.

Purified polyclonal antibodies by Sepharose-hPLAP had a final concentration of $1.6 \mathrm{~g} / \mathrm{L}$, whereas purified polyclonal antibodies by Sepharose-aa 57-71 peptide had a final concentration of $0.92 \mathrm{~g} / \mathrm{L}$.

\section{Immunoassay characteristics}

The standard curve was linear between $0.1 \mathrm{U} / \mathrm{L}$ and $11 \mathrm{U} / \mathrm{L}$ (Figure 1), and the detection limit (defined as the mean +4 $\mathrm{SD}$ of the absorbance of the zero standard for ALP) was $0.1 \mathrm{U} / \mathrm{L}$, for both ICA-PLAP and ICA-PEP assays.

The intra- and interassay variability $(n=12)$ was assessed by measuring 2 pregnant serum pools with a mean PLAP activity of 5.5 and $0.75 \mathrm{U} / \mathrm{L}$ for ICA-PLAP, and 4.8 and $0.98 \mathrm{U} / \mathrm{L}$ for ICA-PEP. The mean intra- and interassay CV were $6.5 \%$ and $9.9 \%$, respectively, for the ICA-PLAP assay, and $3.7 \%$ and $9 \%$, respectively, for the ICA-PEP assay.

Cross-reactions in the ICA-PLAP assay were noted at IAP concentrations of $55 \mathrm{U} / \mathrm{L}$ and $27.5 \mathrm{U} / \mathrm{L}$, exhibiting activity of $1.22 \mathrm{U} / \mathrm{L}$ and $0.75 \mathrm{U} / \mathrm{L}$, respectively. At IAP concentrations $55 \mathrm{U} / \mathrm{L}$, the activity for the ICA-PEP assay was $0.4 \mathrm{U} / \mathrm{L}$. No cross-reactivity was noted for heated IAP in either assay; showing that IAP is very sensitive to high temperature. 


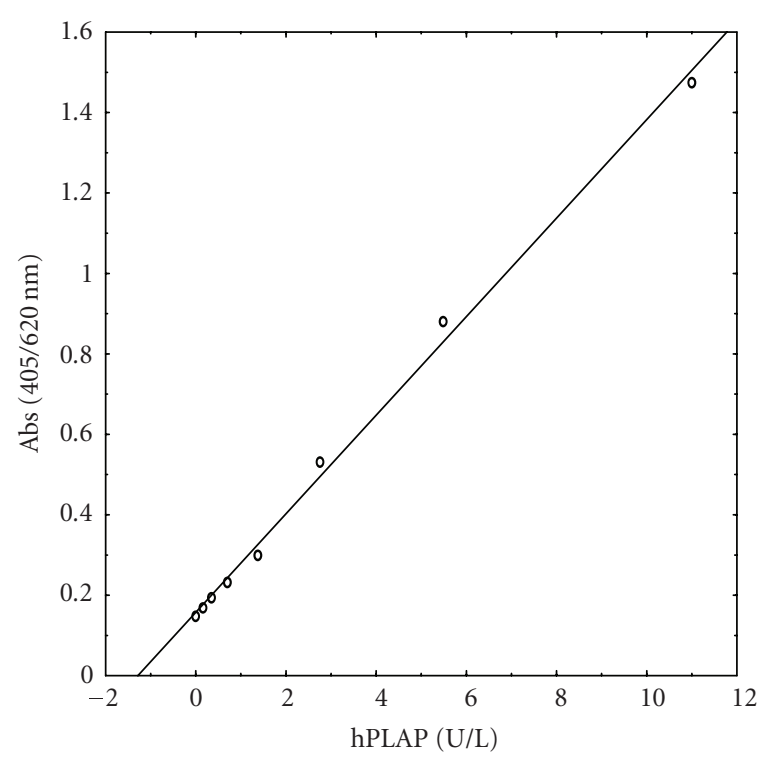

(a)

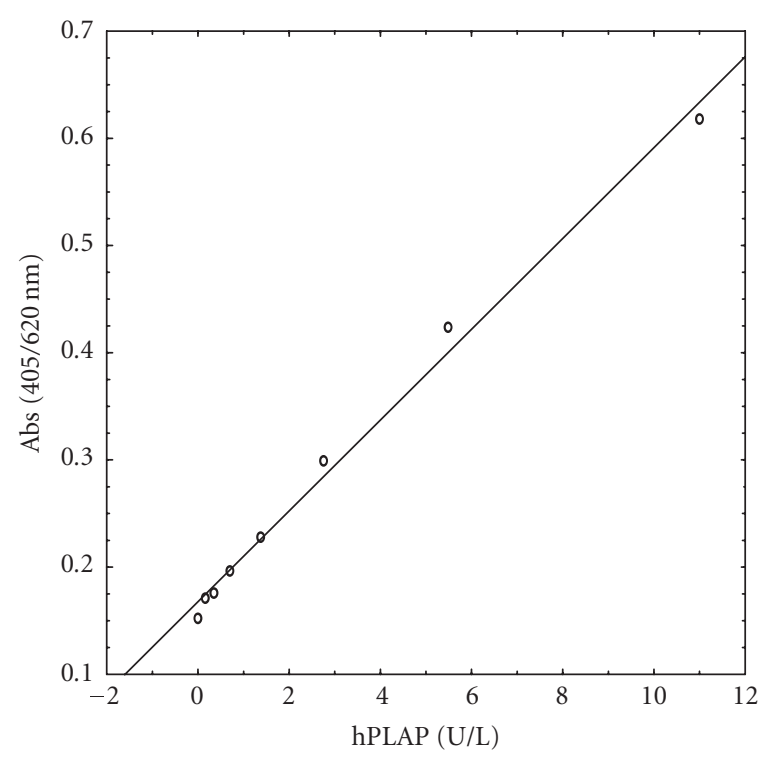

(b)

FIGURE 1: Representative standard curve for the (a) ICA-PLAP and (b) ICA-PEP assays.

\section{Results from serum blood donors}

Average hPLAP/PLAP-like activity for nonsmoker blood donors was $0.06 \pm 0.12 \mathrm{U} / \mathrm{L}$ (mean $\pm \mathrm{SD}$ ), using the ICAPLAP assay, and $0.01 \pm 0.04 \mathrm{U} / \mathrm{L}($ mean $\pm \mathrm{SD})$ with the ICAPEP assay. Smokers had hPLAP/PLAP-like enzyme activities ranging from $0-1.72 \mathrm{U} / \mathrm{L}$, with a mean activity of $0.36 \pm$ $0.41 \mathrm{U} / \mathrm{L}$ (mean $\pm \mathrm{SD}$ ), as determined by the ICA-PLAP assay, and activities from $0-1.65 \mathrm{U} / \mathrm{L}$, with a mean activity of $0.25 \pm 0.36 \mathrm{U} / \mathrm{L}$ (mean $\pm \mathrm{SD}$ ), using the ICA-PEP assay. Figure 2 shows the distribution of serum hPLAP/PLAP-like activities from blood donors measured by the ICA-PLAP and ICA-PEP assays.

The correlation between the ICA-PLAP and ICA-PEP results in blood donors was high $(n=93, r=0.94)$, supporting a rationale for the use of both assays. Heat inactivation did not interfere with hPLAP/PLAP-like activity for nonsmoker or smoker blood donors in either assay.

The hPLAP/PLAP-like enzyme activity cutoff valuedefined as the 90th percentile for the ICA-PLAP assay and the 100th percentile for the ICA-PEP assay-for nonsmokers was $0.2 \mathrm{U} / \mathrm{L}$ for both assays. Based on the present data, we propose a normal hPLAP/PLAP-like enzyme activity cutoff value ranging from $0-0.4 \mathrm{U} / \mathrm{L}$ for smokers, but further analyses are necessary to confirm this threshold.

\section{Pregnant sera results}

Serum samples from 7 pregnant patients were measured without heating (NI) and after heat inactivation (I). hPLAP activities ranged from $0.1-53 \mathrm{U} / \mathrm{L}$. The pregnant patient at the 12th week of gestation had very low hPLAP activity. The pregnant patient at the 18th week of gestation had low hPLAP activity (1.58-2.5 U/L). Patients from the 27 th week to the 37th week of gestation had hPLAP activities that ranged from 31-53 U/L (Table 1). There were no differences identified in hPLAP activities when comparing inactivated and noninactivated samples using either the ICA-PLAP or ICA-PEP assays.

\section{Case report}

The 11.2-year-old patient with ovary embryonal carcinoma was admitted with a visible and palpable abdominal mass. Before chemotherapy (4 cycles of Ifosfamide and cisplatin, at intervals of 21 days), NI and I serum samples had hPLAP/PLAP-like enzyme activity of $9.5 \mathrm{U} / \mathrm{L}$ and $10.2 \mathrm{U} / \mathrm{L}$, respectively, in the ICA-PLAP assay, and 9.3 U/L (NI and I serum) in the ICA-PEP assay. On the 7th day after first cycle of chemotherapy the mass was palpable but not visible anymore, and hPLAP/PLAP-like activity in serum was 5.7 U/L (NI) and 5.6 U/L (I), respectively, in the ICA-PLAP assay, and 5.7 U/L (NI) and 5.3 U/L (I) in the ICA-PEP assay. On the 14th day after first cycle of chemotherapy the abdominal mass was not palpable anymore and hPLAP/PLAPlike activity in serum was $0.23 \mathrm{U} / \mathrm{L}(\mathrm{NI})$ and $0.25 \mathrm{U} / \mathrm{L}(\mathrm{I})$, respectively, in the ICA-PLAP assay, and $0.25 \mathrm{U} / \mathrm{L}$ (NI and I) in the ICA-PEP assay. Forty-two days after initiating chemotherapy a CT scan showed evidence of complete tumor regression, and the hPLAP/PLAP-like enzyme activity in serum was stable; exhibiting $0.22 \mathrm{U} / \mathrm{L}$ (NI) and $0.20 \mathrm{U} / \mathrm{L}(\mathrm{I})$, respectively, for ICA-PLAP, and $0.23 \mathrm{U} / \mathrm{L}$ (NI) and $0.22 \mathrm{U} / \mathrm{L}$ (I) for ICA-PEP. hPLAP/PLAP-like enzyme activity in serum was undetectable, 210 days following initiation of chemotherapy (Figure 3). After 4 cycles of chemotherapy (ifosfamide/CDDP/VP16) complete tumor regression was confirmed using imaging analysis, exploratory surgery, and histological analysis. 

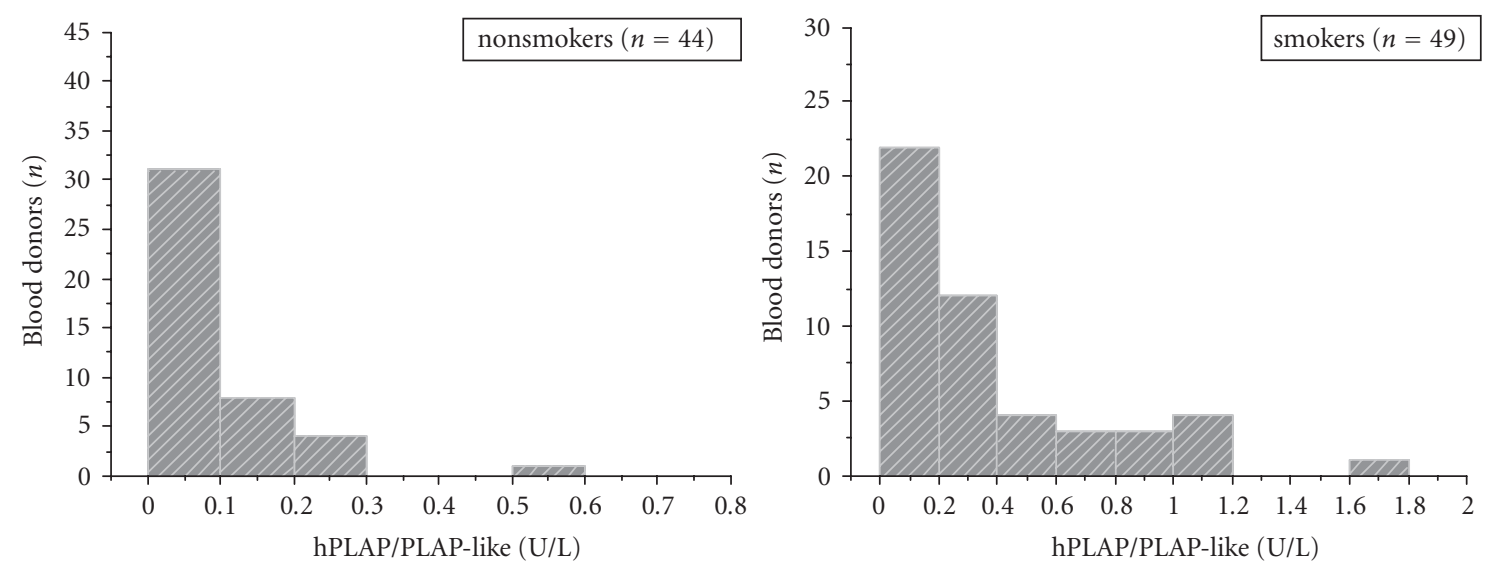

(a)
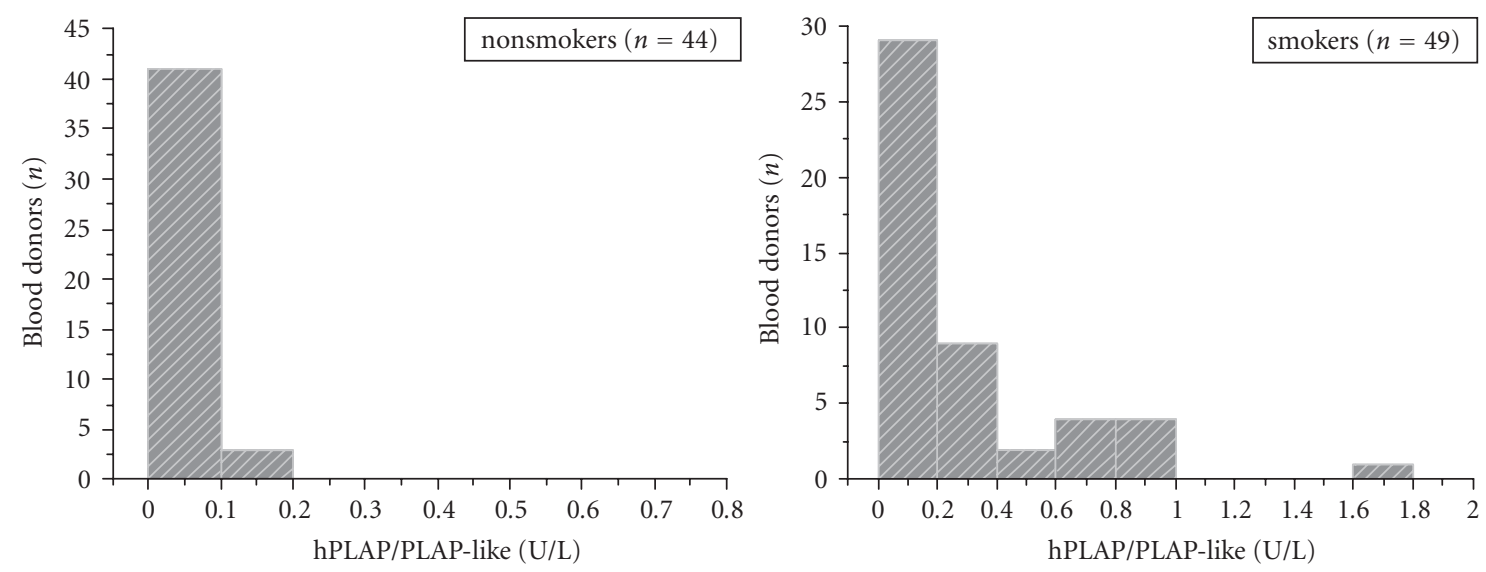

(b)

FIGURE 2: Distribution of hPLAP/PLAP-like activity in serum of blood donors grouped according to smoking habits ( $n=93$ ) for (a) ICAPLAP and (b) ICA-PEP assays.

TABLE 1: hPLAP activities in noninactivated (NI) and heat-inactivated (I) pregnant serum measured by ICA-PLAP and ICA-PEP.

\begin{tabular}{|c|c|c|c|c|c|c|}
\hline \multirow{2}{*}{ Serum sample } & \multirow{2}{*}{ Patient age (years) } & \multirow{2}{*}{ Time of pregnancy (weeks) } & \multicolumn{2}{|c|}{ ICA-PLAP hPLAP (U/L) } & \multicolumn{2}{|c|}{ ICA-PEP hPLAP (U/L) } \\
\hline & & & NI & I & NI & I \\
\hline 1 & 35 & 12 & 0.1 & 0.1 & 0.1 & 0.2 \\
\hline 2 & 33 & 18 & 1.58 & 1.7 & 2 & 2.5 \\
\hline 3 & 28 & 27 & 33 & 35.5 & 36 & 35.5 \\
\hline 4 & 26 & 32 & 31 & 31 & 34 & 32 \\
\hline 5 & 24 & 33 & 51.5 & 49 & 53 & 52 \\
\hline 5 & 32 & 35 & 42 & 44 & 40.2 & 43 \\
\hline 6 & 27 & 37 & 43 & 42 & 41 & 44 \\
\hline
\end{tabular}

\section{DISCUSSION}

Immunoassays for hPLAP using monoclonal or polyclonal antibodies generally do not distinguish PLAP from PLAPlike enzymes because of the high homology between these isoforms [6]. Polyclonal antibodies raised against PLAP may cross-react with IAP $[29,49]$ but this can be minimized by serum heat inactivation. Monoclonal antibodies may not detect hPLAP/PLAP-like enzyme activity if the epitope is not present in the polymorphic protein $[7,45,46]$. The hPLAP enzyme is more polymorphic (at least 48 phenotypes) than the PLAP-like enzyme (10 phenotypes) $[8,9,11,12]$.

Two cost-effective, specific, and sensitive immunoassays were developed for determining hPLAP/PLAP-like enzyme 


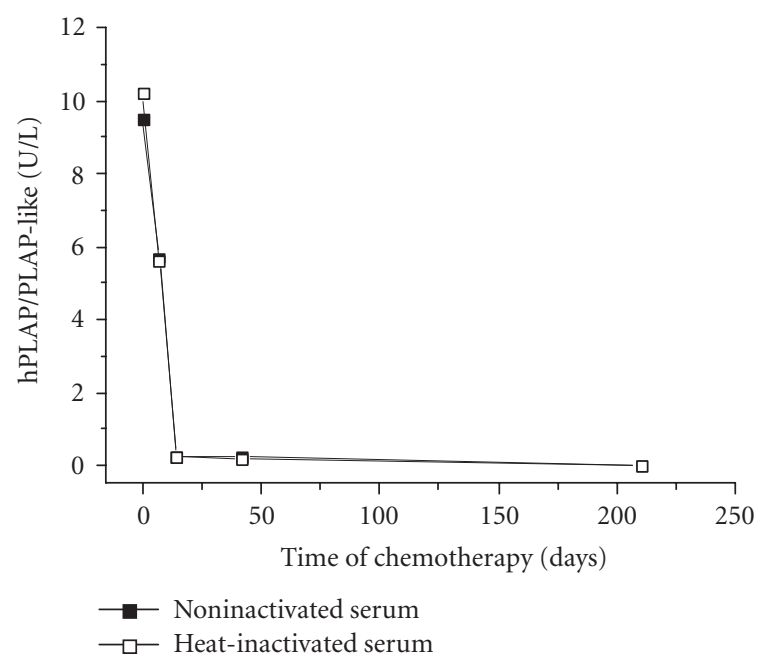

(a)

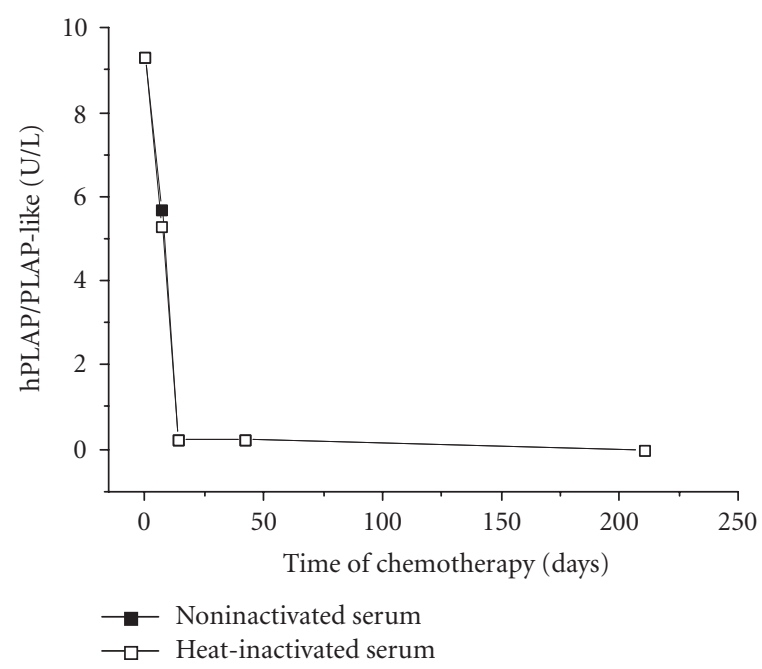

(b)

FIGURE 3: hPLAP/PLAP-like activities in the sera of a 11.2-year-old child with embryonal carcinoma measured by (a) ICA-PLAP and (b) ICA-PEP assays. Forty-two days after initiating chemotherapy a CT scan revealed evidence of complete tumor regression.

activity. Two polyclonal antibodies were selected by affinity chromatography; one PLAP-Ab that is capable of recognizing most PLAP/PLAP-like epitopes that are not recognized by monoclonal antibodies, and a second antibody (PEP-Ab) used in the ICA-PEP that recognizes the aa 57-71 sequence of hPLAP. PLAP/PLAP-like activity determined by PLAP$\mathrm{Ab}$ was, as expected, inferior to PEP-Ab, suggesting that the second antibody may present monoclonal characteristics. A substitution of 1 amino acid in an antigen may modify the antibody-binding activities [28]. The synthetic peptide used in this study differs in 3 amino acids from IAP and 9 amino acids from TNAP [6], and had 15 amino acid residues (the minimum necessary to build an epitope that may comprise 15-22 amino acid residues [50]); suggesting that PEP-Ab recognizes PLAP specific epitope(s).

The sensitivity for both ICA-PLAP and ICA-PEP assays was $0.1 \mathrm{U} / \mathrm{L}$; similar to observations in studies that used antihPLAP monoclonal antibodies $[31,51]$. Cross- reactivity was observed for high levels of IAP (27.5 U/L and $55 \mathrm{U} / \mathrm{L})$ in the ICA-PLAP and ICA-PEP assays, respectively. This interference could be abolished when IAP was inactivated by heating. The ICA-PLAP and ICA-PEP assays were highly correlated $(r=0.94)$. The ICA-PLAP assay is less specific, but more cost-effective than ICA-PEP. Although ICA-PEP was capable of recognizing similar PLAP/PLAP-like activity in heated and unheated samples, ICA-PLAP would reveal other PLAP/PLAP-like phenotypes in unheated samples. Taken together, a combined assay using each of the antibodies may minimize the disadvantage of using monoclonal and polyclonal antibodies. For instance, hPLAP/PLAP-like activity in unheated serum samples from 5 nonsmokers was found slightly above $(\leq 0.6 \mathrm{U} / \mathrm{L})$ cutoff value $(0.2 \mathrm{U} / \mathrm{L})$ only in the ICA-PLAP assay, suggesting that these findings were due to cross-reaction with IAP; as described in other studies $[29,49]$. IAP activity in serum is related to diet and blood group status [52].
Our data show that the normal serum value for PLAP/ PLAP-like enzyme activity in adult nonsmokers is around $0.2 \mathrm{U} / \mathrm{L}$. A normal Gaussian distribution of hPLAP/PLAPlike enzyme activity was not observed in serum of healthy individuals who smoked. Such heterogeneity among these individuals and the resulting high standard deviation in average values have been reported in previous studies $[39,51]$. In the literature, PLAP activity in lung tissue was reported to correspond to PLAP activity in placenta, while PLAP in serum of smokers was reported as PLAP-like activity $[21,51]$; this discrepancy is not well understood. The proposed cutoff corresponding to hPLAP/PLAP-like findings in serum of smokers without cancer in this study was $0.4 \mathrm{U} / \mathrm{L}$, however, this must be better evaluated with serial sampling and while considering the clinical status of the individual. PLAP/PLAPlike enzyme activity measured in serum of smokers probably originates from the lungs (pneumocytes), where cellular damage caused by cigarette smoke may release PLAP-like enzymes into the blood $[21,39]$, possibly in proportion to the duration and intensity of smoking $[39,53]$.

PLAP activity in serum samples from pregnant patients measured by ICA-PLAP and ICA-PEP assays showed no difference between heat-inactivated and noninactivated samples, indicating that the circulating protein is mostly PLAP released by the placenta. As expected, hPLAP activity increased linearly with the advance of pregnancy, as the placental syncytiotrophoblast produces high PLAP levels during the 27 th to 37 th weeks of gestation. This relationship suggests that the monitoring of hPLAP activity could be used as an additional tool to evaluate placenta viability.

Since PLAP/PLAP-like activity could be detected at very low levels in early stages of pregnancy and in smoking individuals, the developed assays could also be used to detect PLAP/PLAP-like activity in the serum of cancer patients. In fact, this immunoassay was possible and extremely useful in the follow-up of a young female patient with 
embryonal carcinoma. Following the first cycle of chemotherapy, PLAP/PLAP-like serum activity decreased in proportion to the size of tumor. This suggests that the immunoassay of PLAP/PLAP-like serum activity may be a good marker for monitoring response to chemotherapy or eventual cancer recurrence, minimizing the need for exhaustive imaging analyses. To further validate PLAP/PLAP-like serum activity as a tumor marker, more serum samples from patients with cancer are necessary. As reported by other authors, increased levels of PLAP/PLAP-like were observed in 2 patients with recurrent testicular seminoma 2 months before detection by CT scan [42]. The longest interval found between increased levels of PLAP/PLAP-like and posterior cancer detection by imaging analysis was 2 years in a woman with a very small ovarian cancer [54]. Determination of PLAP/PLAP-like activity using immunoassays could be particularly useful for serum of patients with testicular cancer and ovarian carcinomas, as is the case for more sensitive markers such as CA 125 and AFP. In fact, PLAP/PLAP-like activity seems to be more specific than CA 125 and AFP [31]. HCG and AFP are used as tumor markers for nonseminomatous testicular cancer, but PLAP/PLAP-like activity is the best tumor marker for the follow-up of patients with seminomas [39].

The ICA-PLAP and ICA-PEP immunoassays could be explored to detect hPLAP/PLAP-like activity above $0.2 \mathrm{U} / \mathrm{L}$ (cutoff value in adults) in physiological and pathological conditions, especially in patients with embryonal cancer or other types of cancer reported in other studies (testis, ovary, lung, and colorectal tract). Furthermore, it can be concluded that ICA-PEP assay is more specific than ICA-PLAP, which is still useful to detect other PLAP/PLAP-like phenotypes that eventually may not be detected by ICA-PEP. Heating inactivation of samples may eliminate IAP and other alkaline phosphatase activity and eventually also decrease PLAP/PLAPlike activity, but this unwished effect could be confirmed by testing unheated samples in the ICA-PEP assay.

\section{ACKNOWLEDGMENTS}

This study was supported by Fundação Araucária-PR (Grant \#2648) and CAPES-COFECUB. Additional funding came from the American Lebanese Syrian Associated Charities (ALSAC), Memphis, Tenn, and from the NIH/NCMHD Grant 9T37MD001378-04 (MHIRT). We are grateful to Dr Luiz Juliano Neto, from Biophysics Laboratory of UNIFESP (São Paulo, Brazil), for providing synthetic peptides.

\section{REFERENCES}

[1] Lehto MT, Sharom FJ. Proximity of the protein moiety of a GPI-anchored protein to the membrane surface: a FRET study. Biochemistry. 2002;41(26):8368-8376.

[2] Moss DW. Perspectives in alkaline phosphatase research. Clinical Chemistry. 1992;38(12):2486-2492.

[3] Low MG, Prasad ARS. A phospholipase D specific for the phosphatidylinositol anchor of cell-surface proteins is abundant in plasma. Proceedings of the National Academy of Sciences of the United States of America. 1988;85(4):980-984.
[4] Posen S, Neale FC, Clubb JS. Heat inactivation in the study of human alkaline phosphatases. Annals of Internal Medicine. 1965;62:1234-1243.

[5] Harris H. The human alkaline phosphatases: what we know and what we don't know. Clinica Chimica Acta. 1990;186(2): 133-150.

[6] Le Du MH, Stigbrand T, Taussig MJ, Ménez A, Stura EA. Crystal structure of alkaline phosphatase from human placenta at 1.8 Å resolution: implication for a substrate specificity. Journal of Biological Chemistry. 2001;276(12):9158-9165.

[7] Beckman G, Beckman L. The placental alkaline phosphatase polymorphism. Variations in Hawaiian subpopulations. $\mathrm{Hu}$ man Heredity. 1969;19(5):524-529.

[8] Sato M, Furiya K, Tanaka S, Sakagishi Y, Komoda T. Allelic polymorphism of human placental alkaline phosphatase in three races: sugar chain heterogeneities. Clinica Chimica Acta. 1988;178(1):101-108.

[9] Millán JL, Fishman WM. Biology of human alkaline phosphatases with special reference to cancer. Critical Reviews in Clinical Laboratory Sciences. 1995;32(1):1-39.

[10] Millán JL, Eriksson A, Stigbrand T. A possible new locus of alkaline phosphatase expressed in human testis. Human Genetics. 1982;62(4):293-295.

[11] Martin D, Tucker DF, Gorman P, Sheer D, Spurr NK, Trowsdale J. The human placental alkaline phosphatase gene and related sequences map to chromosome 2 band q37. Annals of Human Genetics. 1987;51(pt 2):145-152.

[12] Millán JL, Manes T. Seminoma-derived Nagao isozyme is encoded by a germ-cell alkaline phosphatase gene. Proceedings of the National Academy of Sciences of the United States of America. 1988;85(9):3024-3028.

[13] Le Du MH, Millán JL. Structural evidence of functional divergence in human alkaline phosphatases. Journal of Biological Chemistry. 2002;277(51):49808-49814.

[14] Fishman L, Miyayama H, Driscoll SG, Fishman WH. Developmental phase specific alkaline phosphatase isoenzymes of human placenta and their occurrence in human cancer. Cancer Research. 1976;36(7 pt 1):2268-2273.

[15] Makiya R, Stigbrand T. Placental alkaline phosphatase as the placental IgG receptor. Clinical Chemistry. 1992;38(12):25432545.

[16] Beckman G, Beckman L, Holm S, Sikstrom C, Wennberg C. Placental alkaline phosphatase types and transplacental IgG transport. Human Heredity. 1995;45(1):1-5.

[17] Goldstein DJ, Rogers C, Harris H. A search for trace expression of placental-like alkaline phosphatase in non-malignant human tissues: demonstration of its occurrence in lung, cervix, testis and thymus. Clinica Chimica Acta. 1982;125(1):63-75.

[18] Hustin J, Collette J, Franchimont P. Immunohistochemical demonstration of placental alkaline phosphatase in various states of testicular development and in germ cell tumours. International Journal of Andrology. 1987;10(1):29-35.

[19] Muensch HA, Maslow WC, Azama F, Bertrand M, Dewhurst P, Hartman B. Placental-like alkaline phosphatase. Re-evaluation of the tumor marker with exclusion of smokers. Cancer. 1986;58(8):1689-1694.

[20] Hirano K, Matsumoto H, Tanaka T, et al. Specific assays for human alkaline phosphatase isozymes. Clinica Chimica Acta. 1987;166(2-3):265-273.

[21] Williams GH, McLaughlin PJ, Johnson PM. Tissue origin of serum placental-like alkaline phosphatase in cigarette smokers. Clinica Chimica Acta. 1986;155(3):329-333. 
[22] Haije WG, Van Driel J, Van Der Burg MEL. Catalytic and immunologic activities of placental-like alkaline phosphatase in clinical studies. The value of PLAP in follow-up of ovarian cancer. Clinica Chimica Acta. 1987;165(2-3):165-175.

[23] Weissbach L, Bussar-Maatz R, Mann K. The value of tumor markers in testicular seminomas. Results of a prospective multicenter study. European Urology. 1997;32(1):16-22.

[24] Wada N, Chou JY. Characterization of upstream activation elements essential for the expression of germ cell alkaline phosphatase in human choriocarcinoma cells. Journal of Biological Chemistry. 1993;268(19):14003-14010.

[25] Nouri AME, Torabi-Pour N, Dabare AANPM. A new highly specific monoclonal antibody against placental alkaline phosphatase: a potential marker for the early detection of testis tumour. BJU International. 2000;86(7):894-900.

[26] Roelofs H, Manes T, Janszen T, Millán JL, Oosterhuis JW, Looijenga LHJ. Heterogeneity in alkaline phosphatase isozyme expression in human testicular germ cell tumours: an enzyme/immunohistochemical and molecular analysis. Journal of Pathology. 1999;189(2):236-244.

[27] Hendrix PG, Hoylaerts MF, Nouwen EJ, De Broe ME. Enzyme immunoassay of human placental and germ-cell alkaline phosphatase in serum. Clinical Chemistry. 1990;36(10):17931799.

[28] Hoylaerts MF, Millán JL. Site-directed mutagenesis and epitope-mapped monoclonal antibodies define a catalytically important conformational difference between human placental and germ cell alkaline phosphatase. European Journal of Biochemistry. 1991;202(2):605-616.

[29] Malkin A, Kellen JA, Lickrish GM, Bush RS. Carcinoembryonic antigen (CEA) and other tumor markers in ovarian and cervical cancer. Cancer. 1978;42(3 suppl):1452-1456.

[30] Mano H, Furuhashi Y, Morikawa Y, Hattori SE, Goto S, Tomoda Y. Radioimmunoassay of placental alkaline phosphatase in ovarian cancer sera and tissues. Obstetrics and Gynecology. 1986;68(6):759-764.

[31] Nozawa S, Udagawa Y, Ohkura H, et al. Serum placental alkaline phosphatase (PLAP) in gynecologic malignancies - with special reference to the combination of PLAP and CA54/61 assay. Clinica Chimica Acta. 1990;186(2):275-284.

[32] Fisken J, Leonard RCF, Shaw G, Bowman A, Roulston JE. Serum placental-like alkaline phosphatase (PLAP): a novel combined enzyme linked immunoassay for monitoring ovarian cancer. Journal of Clinical Pathology. 1989;42(1):40-45.

[33] Vergote IB, Abeler VM, Bormer OP, Stigbrand T, Trope C, Nustad K. CA125 and placental alkaline phosphatase as serum tumor markers in epithelial ovarian carcinoma. Tumor Biology. 1992;13(3):168-174.

[34] Berek JS, Bast RC Jr. Ovarian cancer screening: the use of serial complementary tumor markers to improve sensitivity and specificity for early detection. Cancer. 1995;76(10 suppl): 2092-2096.

[35] Ind T, Iles R, Shepherd J, Chard T. Serum concentrations of cancer antigen 125, placental alkaline phosphatase, cancerassociated serum antigen and free beta human chorionic gonadotrophin as prognostic markers for epithelial ovarian cancer. British Journal of Obstetrics and Gynaecology. 1997;104(9):1024-1029.

[36] Jeppsson A, Wahren B, Stigbrand T, Edsmyr F, Andersson L. A clinical evaluation of serum placental alkaline phosphatase in seminoma patients. British Journal of Urology. 1983;55(1):7378.
[37] Tucker DF, Oliver RTD, Travers P, Bodmer WF. Serum marker potential of placental alkaline phosphatase-like activity in testicular germ cell tumours evaluated by H17E2 monoclonal antibody assay. British Journal of Cancer. 1985;51(5):631-639.

[38] Ford TF, Butcher DN, Samuell CT, Masters JR, Parkinson MC, Oliver RT. Serum and tissue tumour markers in seminomas. British Journal of Urology. 1985;57(6):750-754.

[39] De Broe ME, Pollet DE. Multicenter evaluation of human placental alkaline phosphatase as a possible tumor-associated antigen in serum. Clinical Chemistry. 1988;34(10):1995-1999.

[40] Koshida K, Wahren B. Placental-like alkaline phosphatase in seminoma. Urological Research. 1990;18(2):87-92.

[41] Koshida K, Uchibayashi T, Yamamoto H, Yokoyama K, Hirano $\mathrm{K}$. A potential use of a monoclonal antibody to placental alkaline phosphatase (PLAP) to detect lymph node metastases of seminoma. Journal of Urology. 1996;155(1):337-341.

[42] Koshida K, Uchibayashi T, Yamamoto H, Hirano K. Significance of placental alkaline phosphatase (PLAP) in the monitoring of patients with seminoma. British Journal of Urology. 1996;77(1):138-142.

[43] Hofer MD, Browne TJ, He L, Skotheim RI, Lothe RA, Rubin MA. Identification of two molecular groups of seminomas by using expression and tissue microarrays. Clinical Cancer Research. 2005;11(16):5722-5729.

[44] Newlands ES, Holden L, Bagshawe KD. Tumour markers and $\mathrm{POMB} / \mathrm{ACE}$ chemotherapy in the management of ovarian germ cell tumours (GCTs). International Journal of Biological Markers. 1988;3(3):185-192.

[45] Shinoda J, Yamada H, Sakai N, Ando T, Hirata T, Miwa Y. Placental alkaline phosphatase as a tumor marker for primary intracranial germinoma. Journal of Neurosurgery. 1988;68(5): 710-720.

[46] Koshida K, Stigbrand T, Munck-Wikland E, Hisazumi H, Wahren B. Analysis of serum placental alkaline phosphatase activity in testicular cancer and cigarette smokers. Urological Research. 1990;18(3):169-173.

[47] Moura JF, DeLacerda L, Sandrini R, et al. ELISA for determination of human growth hormone: recognition of helix 4 epitopes. Journal of Biomedicine and Biotechnology. 2004;2004(3): 143-149.

[48] Kates SA, Albericio F. Solid-Phase Synthesis: A Practical Guide. New York, NY: Marcel Dekker; 2000.

[49] Millán JL, Stigbrand T. "Sandwich" enzyme immunoassay for placental alkaline phosphatase. Clinical Chemistry. 1981; 27(12):2014-2018.

[50] Laver WG, Air GM, Webster RG, Smith-Gill SJ. Epitopes on protein antigens: misconceptions and realities. Cell. 1990; 61(4):553-556.

[51] McLaughlin PJ, Gee H, Johnson PM. Placental-type alkaline phosphatase in pregnancy and malignancy plasma: specific estimation using a monoclonal antibody in a solid phase enzyme immunoassay. Clinica Chimica Acta. 1983;130(2):199-209.

[52] Price CP. Multiple forms of human serum alkaline phosphatase: detection and quantitation. Annals of Clinical Biochemistry. 1993;30(4):355-372.

[53] Nouwen EJ, Pollet DE, Eerdekens MW, Hendrix PG, Briers TW, De Broe ME. Immunohistochemical localization of placental alkaline phosphatase, carcinoembryonic antigen, and cancer antigen 125 in normal and neoplastic human lung. Cancer Research. 1986;46(2):866-876.

[54] Ben-Arie A, Hagay Z, Ben-Hur H, Open M, Dgani R. Elevated serum alkaline phosphatase may enable early diagnosis of ovarian cancer. European Journal of Obstetrics Gynecology and Reproductive Biology. 1999;86(1):69-71. 


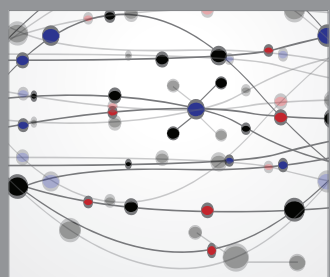

The Scientific World Journal
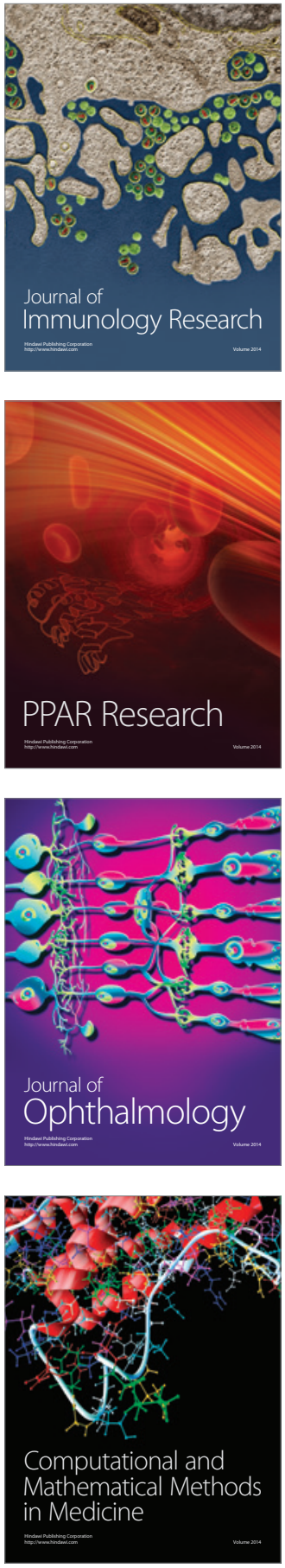

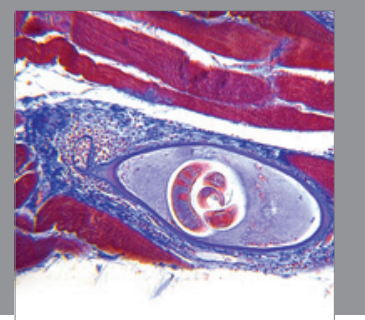

Gastroenterology

Research and Practice
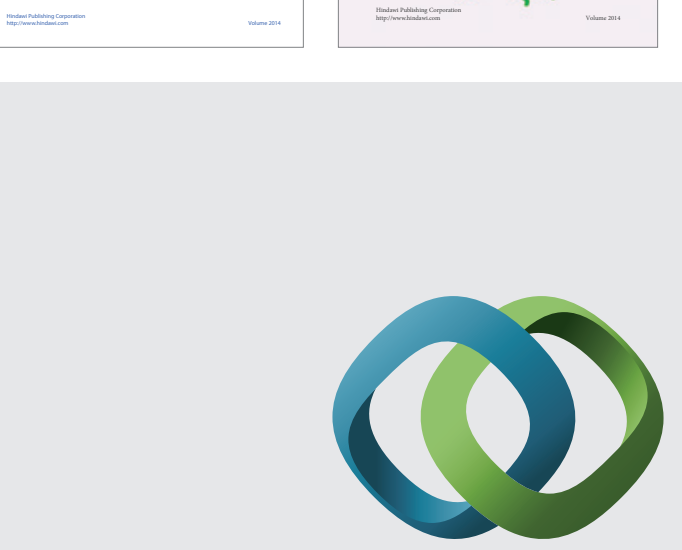

\section{Hindawi}

Submit your manuscripts at

http://www.hindawi.com
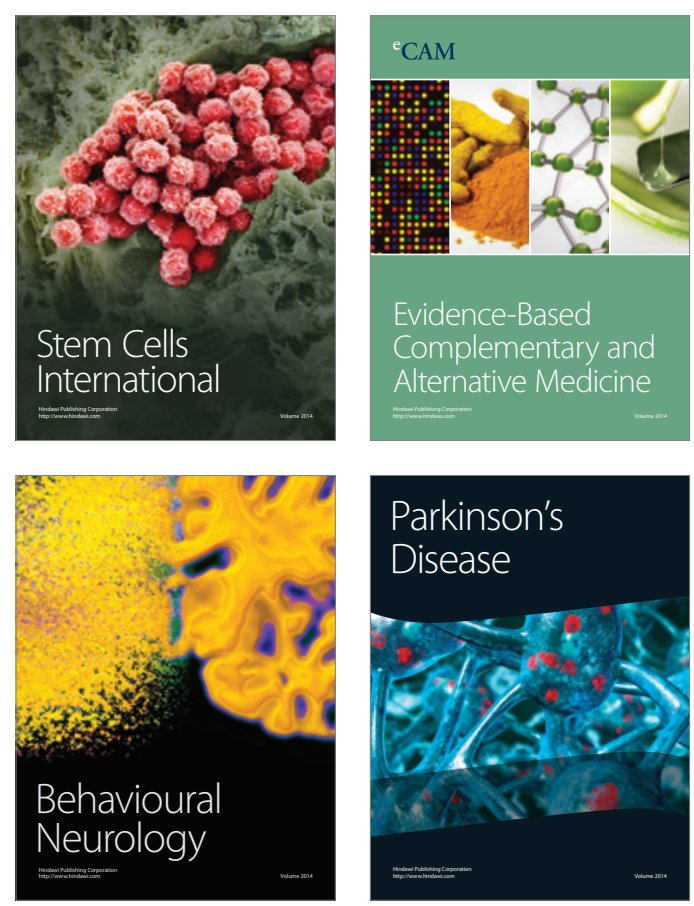

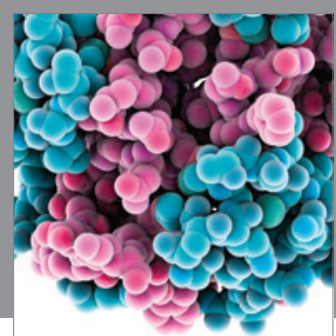

Journal of
Diabetes Research

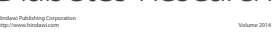

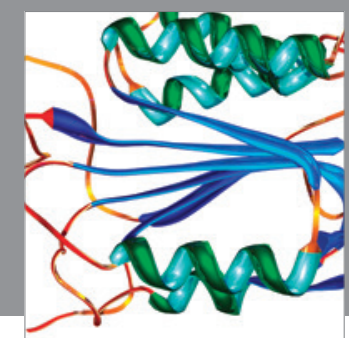

Disease Markers
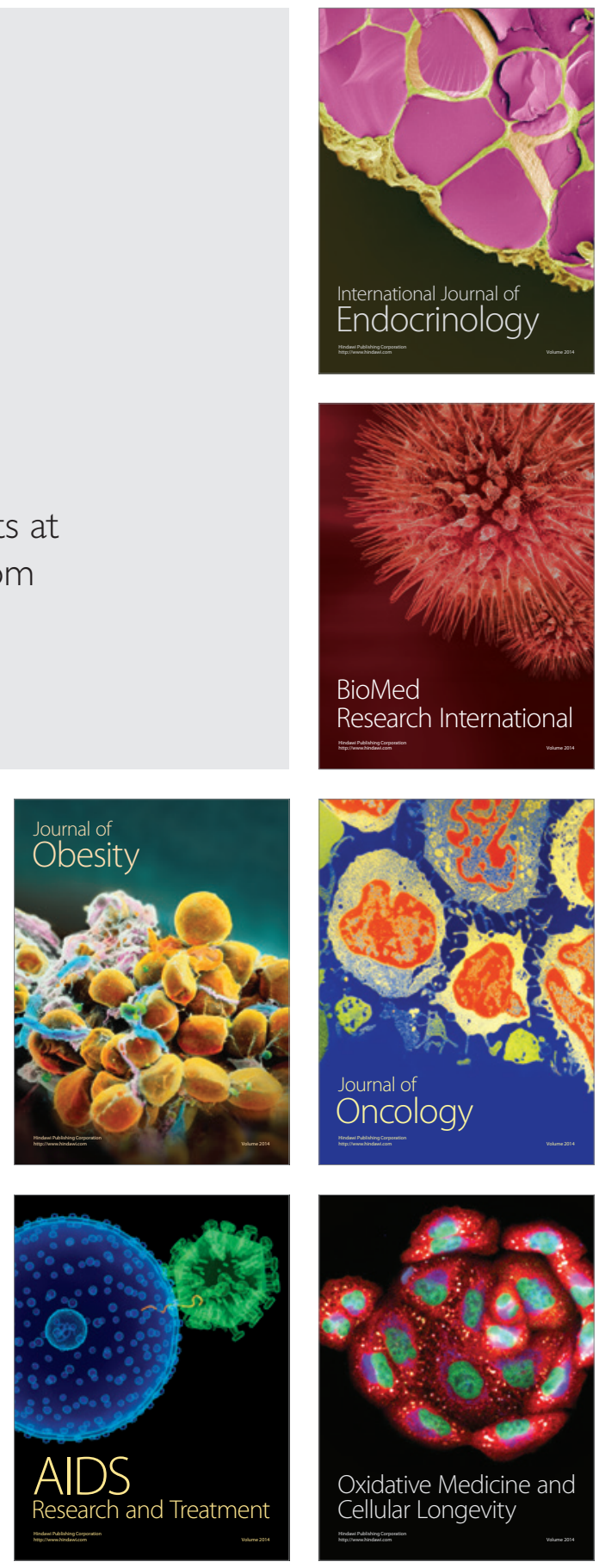